Misr J. Ag. Eng., 26(2): 993- 1005

BIOLOGICAL ENGINEERING

\title{
SHRINKAGE OF NATURAL PLASTERING FOR STRAW BUILDINGS AFFECTED BY REINFORCEMENT AND DRYING
}

\author{
Ashour, T.* and Derbala, A.**
}

\section{ABSTRACT}

This study was carried out to determine the shrinkage percentage of natural plaster materials consisted of soil, sand and different fibres. The experiments were carried out at the Institute of Production Engineering and Buildings Research, Federal Agricultural Research Center (FAL), Braunschweig, Germany in summer 2007. Straw was used as a reinforcement fiber for plaster and three types of fibers. The plaster materials were put under drying temperatures of 30,50 and $70^{\circ} \mathrm{C}$.

The results revealed that the highest shrinkage was for plaster reinforced by wood shaving fibres, while the lowest shrinkage was for plaster reinforced by barley straw fibres for treatments A, B and C. Also, the plaster without reinforcement fibres had a lot of cracks and problems that cause plaster destroyed. The reinforcement fiber has greater effect on the drying shrinkage than sand.

The study recommends using the plaster with $30{ }^{\circ} \mathrm{C}$ drying temperature with a quantity of straw for improving the plaster materials to decrease the shrinkage and cracks.

\section{INTRODUCTION}

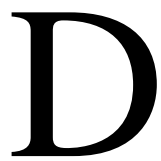
rying shrinkage is one of the main causes of cracks of plaster materials, and so many studies have been made to prevent cracks. Profitable knowledges have been obtained on drying earth plaster. It is very important to study such a traditional problem as crack prevention in view of the drying shrinkage mechanism. Therefore, examination on behavior of properties due to drying is required, when structural application of such materials is considered.

Campbell and Coutts [1980] investigated the possibility of using the wood fibres as reinforcement for a structural composite material. Although wood fibres have relatively poor mechanical properties compared with synthetic fibres, they have the advantages of low density, low cost and low energy demand during manufacture.

*- Lect. of Agric. Eng. Dept., Fac. Agric., Moshtohor, Benha Univ., Egypt.

** - Lect. of Agric. Eng. Dept., Fac. Agric., Tanta Univ., Egypt. 
They indicated that the kraft pulp is suitable for applications where slurry dewatering can be employed during the forming operation and that the thermo mechanical pulp is more suited to applications where low water-cement ratio slurry is used.

Bai et al. [2005] measured the drying shrinkage of concretes with the natural sand replaced with furnace bottom ash (FBA) at $0 \%, 30 \%, 50 \%$, $70 \%$ and $100 \%$ by mass. They mentioned that at fixed water-cement ratios, the compressive strength and the drying shrinkage decreased with the increase of the FBA sand content.

Eve et al. [2006] studied the setting of binary blends such as latex-filled plaster and polyamide fibre-reinforced plaster materials. They showed that the choice of the proper latex to be associated with the plaster was made looking upon its influences on the setting time and the mechanical properties of the blend. Also, the ternary blends were characterized by a drastic increase of the setting time correlated with a reduction of the total swelling.

Omar et al. [2006] compared four types of super plasticizers and used it in conjunction with three types of silica fume to prepare cement concrete slab specimens that were utilized to measure plastic shrinkage strain and time to attain maximum strain. They indicated that the plastic shrinkage strain varied with the type of super plasticizer and the type of silica fume.

Andrea and Harmuth [2008] investigated the mechanisms of crack formation of interior plasters applied on permanent shuttering panels which are used for the erection of concrete in walls. They mentioned that the composition of traditional mud plasters varies from place to place. The clay content is particularly significant, because if it is too low the plaster will lack strength and cohesion, and if it is too high there will be a risk of cracking due to shrinkage, which will weaken the bond to the wall.

Traditionally, clay plasters were often applied in one coat both internally and externally. If applied in two coats, the first coat contains more clay, even if cracks develop, while the second, containing more sand is applied in a thinner layer. The second coat will help to close the micro- 
cracks in the first, provided the surface has been lightly dampened before plastering. Finally, lime distemper or whitewash can be applied to give some additional weatherproofing [Hashmi, 2008].

So, the objective of this work was an attempt to examine fundamentally and physically the drying shrinkage of earth plaster reinforced by different fibres under 30,50 and $70{ }^{\circ} \mathrm{C}$ thermal condition drying.

\section{MATERIALS AND METHODS}

The experimental site was located at the Institute of Production Engineering and Buildings Research, Federal Agricultural Research Center [FAL], Braunschweig, Germany in summer 2007. Three different plaster materials were selected such as soil, sand and reinforcement fiber. Three fiber types such as barley straw, wheat straw and wood shavings were used. Plaster materials were done by mixing the materials with different percentages [25:0:75\%], [25:25:50\%], [25:50:25\%], [25:75:0\%] and [100:0:0\%] [soil: sand: reinforcement fiber] for treatments A, B, C, D and E, respectively. Mixing parts were calculated by dry volume. Soil texture consisted of clay $[<2 \mu \mathrm{m}] 31 \%$, silt [20-63 $\mu \mathrm{m}] 22 \%$ and sand $[63-2000 \mu \mathrm{m}] 47 \%$.

\section{Density:}

Samples density was calculated by using the following equation:

$$
\rho=\frac{\mathrm{W}}{\mathrm{V}}
$$

Where:

$$
\begin{array}{ll}
\rho & : \text { density in } \mathrm{kg} / \mathrm{m}^{3}, \\
\mathrm{~W} & : \text { mass of sample in } \mathrm{kg} \text { and } \\
\mathrm{V} & : \text { sample volume in } \mathrm{m}^{3} .
\end{array}
$$

\section{Shrinkage test:}

Shrinkage test was measured according to ASTM D4943-95, but with different length and specialized equipment. The earth plaster was packed in a steel frame box with interior dimensions of $20 \times 5 \times 5 \mathrm{~cm}$ [length $\mathrm{x}$ width $x$ height]. The box had sides, but no top or bottom and the inside surfaces of the box were smooth to avoid bonding between the steel and the plaster [Fig. 1]. The samples were put in the back oven and dried under different temperatures 30,50 and $70{ }^{\circ} \mathrm{C}$, until the constant weight according to DIN EN ISO 12570: 2000. The shrinkage was measured by 
pushing the complete sample (including separated lumps) tightly up to one end of the box and measuring the gap created by the shrinkage. The shrinkage values were measured by using vernier scale [Fig. 2].

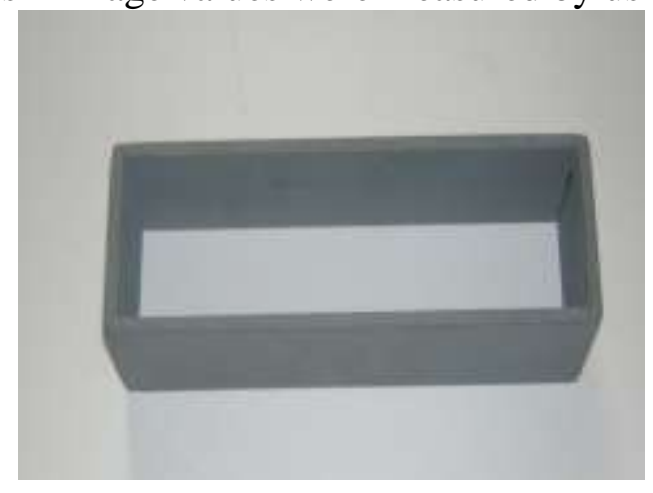

Fig. 1: Frame for sample preparation.

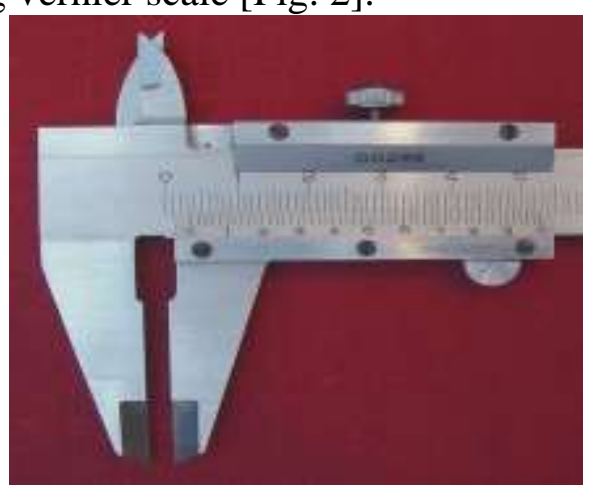

Fig. 2: Vernier scale for measuring the shrinkage.

\section{Moisture content:}

Moisture content for the materials was measured according to [Ashrae, 1997] as follows:

$$
M C .(\%)=\frac{\left(\mathrm{W}_{\mathrm{m}}-\mathrm{W}_{\mathrm{d}}\right)}{\mathrm{W}_{\mathrm{d}}} .100
$$

Where:

$$
\begin{aligned}
& \mathrm{MC} \quad \text { : moisture content (d.b) in } \%, \\
& \mathrm{~W}_{\mathrm{m}} \quad \text { : moist mass in } \mathrm{kg} \text { and } \\
& \mathrm{W}_{\mathrm{d}} \quad \text { : dry mass in } \mathrm{kg} .
\end{aligned}
$$

\section{Shrinkage percentage:}

The shrinkage percentage is the deformation in sample length with the original length. The shrinkage percentage was calculated according to [Lerner and Donahue 2003] as follows:

$$
\text { Shrinkage }(\%)=(\Delta \mathrm{L} / \mathrm{L}) \cdot 100
$$

Where:

$\Delta \mathrm{L} \quad$ : change in height in $\mathrm{cm}$ and

$\mathrm{L} \quad$ : original height in $\mathrm{cm}$.

\section{RESULTS AND DISCUSSIONS}

- The effect of drying temperature on shrinkage for wood shavings plaster 
The densities of plaster material reinforced by wood shaving fibres were 681,1110 and $1435 \mathrm{~kg} / \mathrm{m}^{3}$ for treatments A, B and C, respectively. The relationship between different treatments. The average drying shrinkage values of treatment $\mathrm{A}$ were $1.75,2.64$ and $3.20 \mathrm{~mm}$ for drying temperatures of 30,50 and $70{ }^{\circ} \mathrm{C}$, respectively. Shrinkage values were $1.88,3.0$ and $3.60 \mathrm{~mm}$ for drying temperatures of 30,50 and $70^{\circ} \mathrm{C}$, respectively. On the other hand, shrinkage values of treatment $\mathrm{C}$ were 2.06, 3.7 and $5.40 \mathrm{~mm}$ for drying temperatures of 30,50 and $70^{\circ} \mathrm{C}$, respectively.

The average shrinkage percentages of treatment A were $0.88,1.32$ and $1.60 \%$ for drying temperatures of 30,50 and $70{ }^{\circ} \mathrm{C}$, respectively. At treatment $\mathrm{B}$, shrinkage percentages were $0.94,1.50$ and $1.80 \%$ for different drying temperatures of 30,50 and $70^{\circ} \mathrm{C}$, respectively. Meanwhile, shrinkage percentages of treatment $\mathrm{C}$ were $1.03,1.85$ and $2.70 \%$ for drying temperatures of 30,50 and $70^{\circ} \mathrm{C}$, respectively as shown in Fig. 3.

The results indicated that increasing of drying temperature from 30 to $70{ }^{\circ} \mathrm{C}$ lead to increased shrinkage percentage of $0.72 \%$. Furthermore, increasing wood shavings fibres from 25 to $75 \%$ caused decreasing of shrinkage percentages $0.15,0.53$ and $1.1 \%$ for drying temperatures 30 , 50 and $70{ }^{\circ} \mathrm{C}$, respectively. The results showed that drying temperatures has a great effect on shrinkage of plaster reinforced by wood shaving fibres.

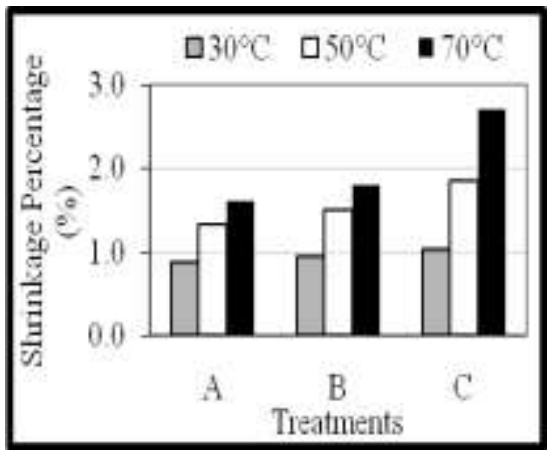

Fig. 3: Shrinkage percentages of plaster reinforced by wood shaving fibres.

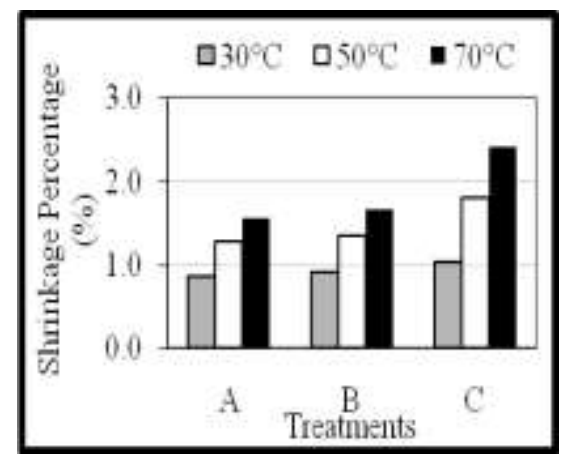

Fig. 4: Shrinkage percentages of plaster reinforced by wheat straw fibres. 


\section{- The effect of drying temperature on shrinkage for wheat straw plaster}

The densities of plaster materials were 594,1099 and $1400 \mathrm{~kg} / \mathrm{m}^{3}$ for treatments $\mathrm{A}, \mathrm{B}$ and $\mathrm{C}$, respectively. For plaster reinforced by wheat straw fibres, the overall shrinkage values of treatment A were 1.70, 2.53 and $3.10 \mathrm{~mm}$ for drying temperatures of 30,50 and $70{ }^{\circ} \mathrm{C}$, respectively. While for treatment $\mathrm{B}$, they were $1.80,2.70$ and $3.30 \mathrm{~mm}$ for different drying temperatures of 30,50 and $70{ }^{\circ} \mathrm{C}$, respectively. Furthermore, shrinkage values of treatment $\mathrm{C}$ were $2.05,3.6$ and $4.80 \mathrm{~mm}$ for drying temperatures of 30,50 and $70^{\circ} \mathrm{C}$, respectively.

For treatment A, shrinkage percentages were $0.85,1.27$ and $1.55 \%$ for drying temperatures of 30,50 and $70{ }^{\circ} \mathrm{C}$, respectively. For treatment $\mathrm{B}$ shrinkage percentages were $0.90,1.35$ and $1.65 \%$ for different drying temperatures of 30,50 and $70{ }^{\circ} \mathrm{C}$, respectively. Moreover, shrinkage percentages of treatment $\mathrm{C}$ were $1.03,1.80$ and $2.40 \%$ for drying temperatures of 30,50 and $70{ }^{\circ} \mathrm{C}$, respectively as shown in Fig. 4.

The results indicated that increasing of drying temperature from 30 to $70{ }^{\circ} \mathrm{C}$ lead to increased shrinkage percentages of $0.70,0.75$ and $1.37 \%$ for treatments A, B and C, respectively. Furthermore, increasing of wheat straw fibres from 25 to $75 \%$ caused decreasing of shrinkage percentages $0.18,0.53$ and $0.85 \%$ for drying temperatures 30,50 and 70 ${ }^{\circ} \mathrm{C}$, respectively.

\section{- The effect of drying temperature on shrinkage for barley straw plaster}

Densities for plaster materials reinforced by barley straw were 584, 1078 and $1391 \mathrm{~kg} / \mathrm{m}^{3}$ for treatments $\mathrm{A}, \mathrm{B}$ and $\mathrm{C}$, respectively. The overall shrinkages for plaster reinforced by barley straw fibres of treatment $\mathrm{A}$ were 1.64, 2.30 and $2.60 \mathrm{~mm}$ for drying temperatures of 30,50 and 70 ${ }^{\circ} \mathrm{C}$, respectively. Meanwhile for treatment $\mathrm{B}$, they were $1.75,2.60$ and $3.10 \mathrm{~mm}$ for different drying temperatures of 30,50 and $70^{\circ} \mathrm{C}$, respectively. On the other hand, shrinkage values of treatment $\mathrm{C}$ were $1.90,3.33$ and $4.60 \mathrm{~mm}$ for drying temperatures of 30,50 and $70^{\circ} \mathrm{C}$, respectively. 
The average shrinkage percentages of treatment $\mathrm{A}$ were $0.82,1.15$ and $1.30 \%$ for drying temperatures of 30,50 and $70{ }^{\circ} \mathrm{C}$, respectively. For treatment B shrinkage percentages were $0.86,1.30$ and $1.55 \%$ for different drying temperatures of 30,50 and $70^{\circ} \mathrm{C}$, respectively. On the other hand, shrinkage percentages of treatment $\mathrm{C}$ were $0.95,1.67$ and $2.30 \%$ for drying temperatures of 30,50 and $70{ }^{\circ} \mathrm{C}$, respectively as shown in Fig. 5.

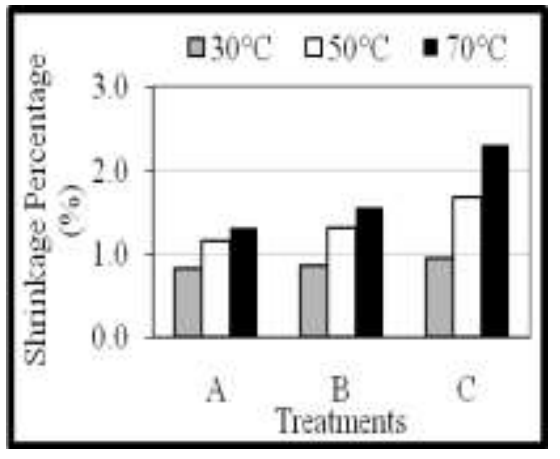

Fig. 5: Shrinkage percentages of plaster reinforced by barley straw fibres.

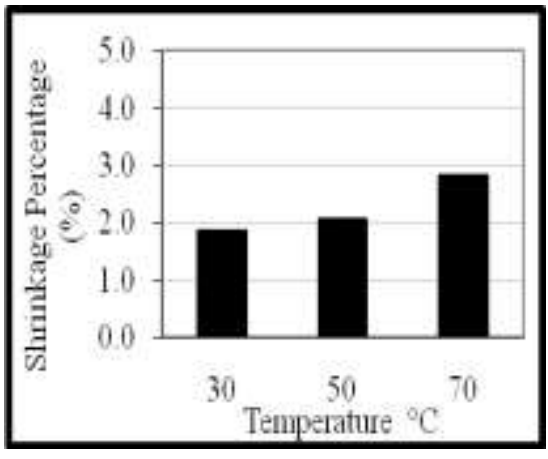

Fig. 6: Shrinkage percentages of sand plaster without reinforcment fibres.

The results indicated that increasing drying temperature from 30 to 70 ${ }^{\circ} \mathrm{C}$ lead to increased shrinkage percentages of $0.48,0.69$ and $1.35 \%$ for treatments A, B and C, respectively. Furthermore, increasing wheat straw fibres from 25 to $75 \%$ caused decreasing of shrinkage percentages $0.13,0.52$ and $1.00 \%$ for drying temperatures of 30,50 and $70{ }^{\circ} \mathrm{C}$, respectively.

\section{- The effect of drying temperature on shrinkage for plaster without reinforcement fibres}

The density of plaster without reinforcement fibres was $1642 \mathrm{~kg} / \mathrm{m}^{3}$. The relationship between different treatments and the shrinkage rate for sand plaster without reinforcement fibres. The average drying shrinkage values were $3.72,4.12$ and $5.61 \mathrm{~mm}$ for drying temperatures of 30, 50 and $70{ }^{\circ} \mathrm{C}$, respectively. The results revealed that shrinkage increased with increasing drying temperature while increasing temperature from 30 to $70{ }^{\circ} \mathrm{C}$ caused increasing of shrinkage value to $1.89 \mathrm{~mm}$. 
The average values of shrinkage percentages for plaster material without reinforcement fibres were 1.86, 2.06 and $2.81 \%$ for drying temperatures of 30,50 and $70{ }^{\circ} \mathrm{C}$, respectively. Also, the shrinkage percentage increased as drying temperature increased while increasing temperature from 30 to $70{ }^{\circ} \mathrm{C}$ caused increasing drying shrinkage to $0.95 \%$ [Fig. 6].

\section{- The effect of drying temperature on shrinkage for clay plaster}

The density of plaster without reinforcement fibres and without sand was $1481 \mathrm{~kg} / \mathrm{m}^{3}$. The average drying shrinkage values were $6.90,7.01$ and $9.13 \mathrm{~mm}$ for drying temperatures of 30,50 and $70{ }^{\circ} \mathrm{C}$, respectively. The results revealed that shrinkage increased as drying temperature increased while increasing temperature from 30 to $70{ }^{\circ} \mathrm{C}$ caused increasing drying shrinkage to $2.23 \mathrm{~mm}$.

The average values of shrinkage percentage for plaster material without reinforcement fibres were $3.45,3.51$ and $4.57 \%$ for drying temperatures of 30,50 and $70{ }^{\circ} \mathrm{C}$, respectively. Also, the shrinkage percentage increased as drying temperature increased while increasing temperature from 30 to $70{ }^{\circ} \mathrm{C}$ caused increasing drying shrinkage to $1.12 \%$ as shown in Fig. 7.

Also, high cracks were shown under drying temperatures of 50 and 70 ${ }^{\circ} \mathrm{C}$ and the sample was fully destroyed [Fig. 8].

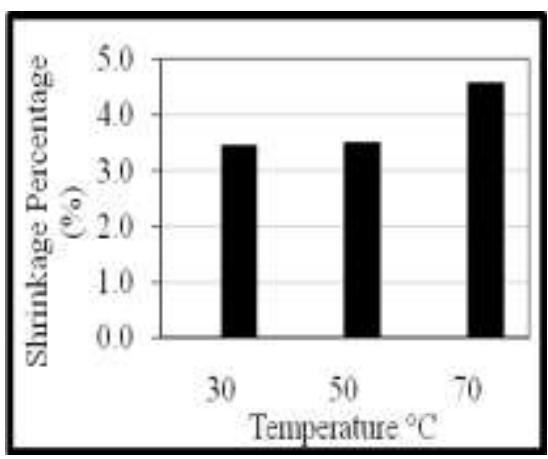

Fig. 7: Shrinkage percentages of clay plaster without sand and reinforcement fibres.

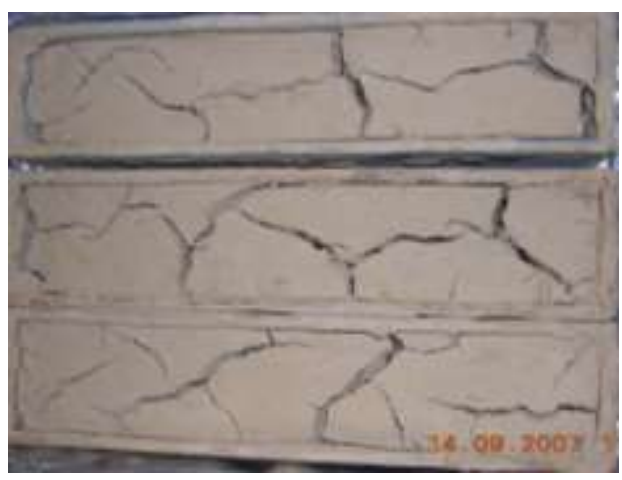

Fig. 8: Shrinkage and cracks for clay samples.

\section{- Comparisons of the different plaster materials under the study}


For treatment A, overall shrinkage values were 1.75, 1.70, 1.64, 3.72 and $6.90 \mathrm{~mm}$ at $30{ }^{\circ} \mathrm{C}$ for plaster reinforced by wood shavings, wheat, barley, without fibers (sand plaster) and clay, respectively. Meanwhile at $50{ }^{\circ} \mathrm{C}$ overall shrinkage values were $2.64,2.53,2.30,4.12$ and $7.01 \mathrm{~mm}$ for wood shavings, wheat, barley, sand and clay plaster, respectively. On the other hand, overall shrinkage values at $70{ }^{\circ} \mathrm{C}$ were $3.20,3.10,2.60$, 5.61 and $9.13 \mathrm{~mm}$ of plaster reinforced with wood shavings, wheat, barley, sand and clay, respectively.

Furthermore, shrinkage percentages were $0.88,0.85,0.82,1.86$ and $3.45 \%$ at $30{ }^{\circ} \mathrm{C}$ for plaster reinforced by wood shavings, wheat, barley, without fibers (sand plaster) and clay, respectively. While at $50{ }^{\circ} \mathrm{C}$, shrinkage values were $1.32,1.27,1.15,2.06$ and $3.51 \%$ for wood shavings, wheat, barley, sand and clay plaster, respectively. On the other hand, overall shrinkage percentages at $70{ }^{\circ} \mathrm{C}$ were $1.60,1.55,1.30,2.81$ and $4.57 \%$ of plaster reinforced with wood shavings, wheat, barley, sand and clay, respectively as shown in Fig. 9.

The results revealed that clay plaster without reinforcement fibres and straw had high shrinkage values with high cracks in the plaster samples. Also, sand plasters without fibres had high shrinkage but lower than only clay. For the reinforcement fibres plasters, the highest shrinkage was for plaster reinforced by wood shavings fibres, while the lowest shrinkage was plaster reinforced by barley straw fibres.

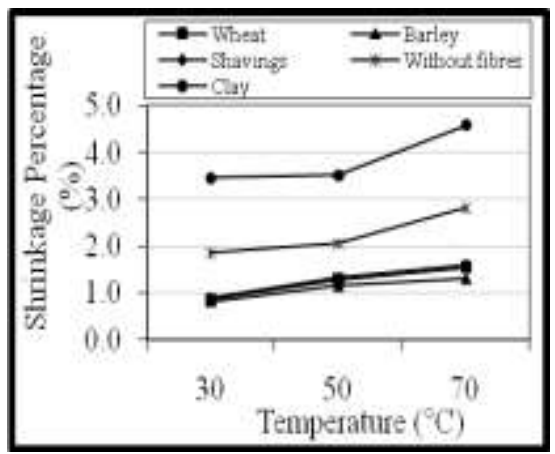

Fig. 9: Shrinkage percentage of different plaster materials for treatment A.

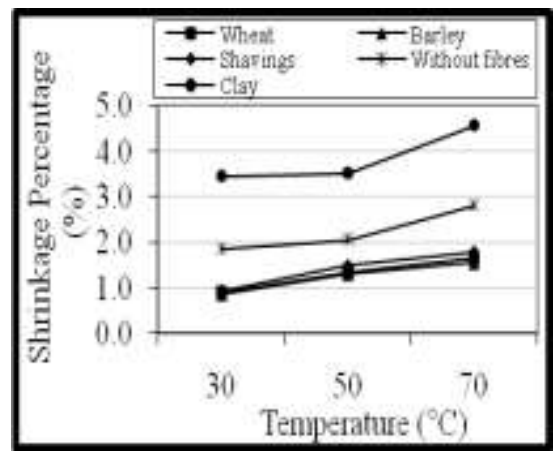

Fig.10: Shrinkage percentage of different plaster materials for treatment B. 
For treatment $\mathrm{B}$, overall shrinkage values were $1.88,1.80,1.75,3.72$ and $6.90 \mathrm{~mm}$ at $30{ }^{\circ} \mathrm{C}$ for plaster reinforced by wood shavings, wheat, barley, without fibers (sand plaster) and clay, respectively. While at 50 ${ }^{\circ} \mathrm{C}$, overall shrinkage values were 3.00, 2.70, 2.60, 4.12 and $7.01 \mathrm{~mm}$ for wood shavings, wheat, barley, sand and clay plaster, respectively. On the other hand, overall shrinkage values at $70{ }^{\circ} \mathrm{C}$ were $3.60,3.30,3.10,5.61$ and $9.13 \mathrm{~mm}$ for plaster reinforced with wood shavings, wheat, barley, sand and clay, respectively.

Furthermore, shrinkage percentages were $0.94,0.90,0.86,1.86$ and $3.45 \%$ at $30{ }^{\circ} \mathrm{C}$ for plaster reinforced by wood shavings, wheat, barley, without fibers (sand plaster) and clay, respectively. While at $50{ }^{\circ} \mathrm{C}$, shrinkage percentages were $1.50,1.35,1.30,2.06$ and $3.51 \%$ for wood shavings, wheat, barley, sand and clay plaster, respectively. On the other hand, overall shrinkage percentages at $70{ }^{\circ} \mathrm{C}$ were $1.80,1.65,1.55,2.81$ and $4.57 \%$ of plaster reinforced with wood shavings, wheat, barley, sand and clay, respectively as shown in Fig. 10.

In treatment $\mathrm{C}$, overall shrinkage values were $2.06,2.05,1.90,3.72$ and $6.90 \mathrm{~mm}$ at $30{ }^{\circ} \mathrm{C}$ for plaster reinforced by wood shavings, wheat, barley, without fibers (sand plaster) and clay, respectively. While at 50 ${ }^{\circ} \mathrm{C}$, overall shrinkages were 3.70, 3.60, 3.33, 4.12 and $7.01 \mathrm{~mm}$ for wood shavings, wheat, barley, sand and clay plaster, respectively. On the other hand, overall shrinkages at $70{ }^{\circ} \mathrm{C}$ were $5.40,4.80,4.60,5.61$ and 9.13 $\mathrm{mm}$ for plaster reinforced with wood shavings, wheat, barley, sand and clay, respectively.

Furthermore, shrinkage percentages were 1.03, 1.03, 0.95, 1.86 and $3.45 \%$ at $30{ }^{\circ} \mathrm{C}$ for plaster reinforced by wood shavings, wheat, barley, without fibers (sand plaster) and clay, respectively. While at $50{ }^{\circ} \mathrm{C}$, shrinkage percentages were $1.85,1.80,1.67,2.06$ and $3.51 \%$ for wood shavings, wheat, barley, sand and clay plaster, respectively. On the other hand, overall shrinkages at $70{ }^{\circ} \mathrm{C}$ were $2.70,2.40,2.30,2.81$ and $4.57 \%$ plaster reinforced with wood shavings, wheat, barley, sand and clay, respectively [Fig. 11]. 


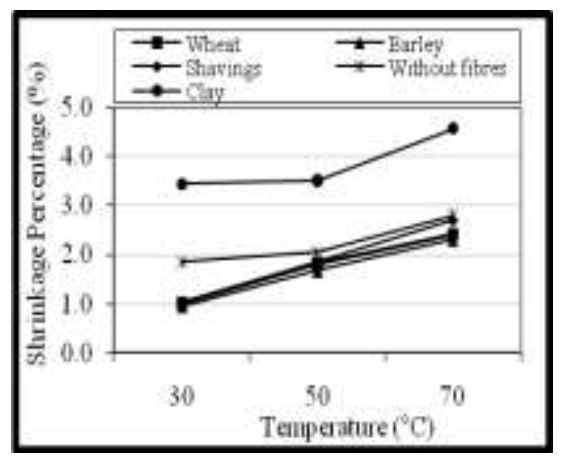

Fig.11: Shrinkage percentage of different plaster materials for treatment C.

The average of shrinkage percentages for treatments $\mathrm{A}, \mathrm{B}$ and $\mathrm{C}$ ranged between $0.82-1.03 \%, 1.15-1.85 \%$ and $2.60-5.40 \%$ for temperatures 30,50 and $70{ }^{\circ} \mathrm{C}$, respectively.

The results confirmed that the highest shrinkage was for plaster reinforced by wood shaving fibres, while the lowest shrinkage was for plaster reinforced by barley straw fibres for treatments A, B and C. The results also revealed that the plaster without reinforcement fibres had a lot of cracks and problems that cause plaster destruction.

\section{CONCLUSIONS}

The results confirmed that:

- The average shrinkage percentages for treatments $\mathrm{A}, \mathrm{B}$ and $\mathrm{C}$ ranged between $0.82-1.03 \%, 1.15-1.85 \%$ and $2.60-5.40 \%$ for temperatures of 30,50 and $70{ }^{\circ} \mathrm{C}$, respectively.

- The highest shrinkage was for plaster reinforced by wood shaving fibres, while the lowest shrinkage was for plaster reinforced by barley straw fibres for treatments A, B and C.

- The plaster without reinforcement had a lot of cracks and problems that cause plaster destruction. Also, the reinforcement fiber had greater effect on the drying shrinkage than sand. The drying temperature had a high effect on shrinkage values as a result of forced desorption from the plaster surfaces.

- The cracks decreased as reinforcement fibres increased and increased as clay and sand content increased. Also, the cracks increased as drying temperatures increased and vice versa. 
It will be better when the plaster cusses at low temperature condition $\left(30{ }^{\circ} \mathrm{C}\right)$ and use a quantity of straw for improving the plaster to decrease shrinkage and cracks.

\section{REFERENCES}

Andrea V. K. and H. Harmuth (2008). Mechanisms to reduce cracking in interior plasters attached to cement bonded permanent shuttering panels. Const. and Build. Mat., 22(2):99-105.

ASHRAE (1997). ASHRAE Handbook, Fundamentals. N. Y. Am. Soc. Heat. and Refrig. and Air Cond. Eng., Inc.

ASTM D4943-(1995). Standard Test Method for Shrinkage Factors of Soils by the Wax Method. Annual Book of ASTM Standards, Vol. 04.08

Bai, Y., F. Darcy and P. A. M. Basheer (2005). Strength and drying shrinkage properties of concrete containing furnace bottom ash as fine aggregate. Const. and Build. Mat., 19(9):691-697.

Campbell, M. D. and R. S. P. Coutts (1980). Wood fibre-reinforced cement composites. J. of Mat. Sci., p:1962-1970.

DIN EN ISO, 12570 (2000). Waerme- und Feuchtetechnisches verhalten von Baustoffen und Bauprodukten-Bestimmung des Feuchtegehaltes durch Trocknen bei erhoehter Temperatur. p:1-4

Eve, S., M. Gomina, J. Hamel and G. Orange (2006). Investigation of the setting of polyamide fibre/latex-filled plaster composites. Const. and Build. Mat., 26(13):2541-2546.

Hashmi, F. (2008). Mud plasters and renders. http://www.appropedia.org/Mud_plasters_and_renders_(Practical_ Action_Brief):last update 1/10/ 2008.

Lerner, K. and K. Donahue (2003). Structural testing of plasters for straw bale construction. Ecobuild Network, www.ecobuildnetwork.org/pdfs/plaster_tests.pdf . Accessed September 14, 2005.

Omar, S., B. Al-Amoudi, O. T. Abiola and M. Maslehuddin (2006). Effect of super plasticizer on plastic shrinkage of plain and silica fume cement concretes. Const. and Build. Mat., 20(9):642-647. 


\section{إنكماش المحارة الطبيعية لمباني القش العربى وثأثز ها بالثقوية والتجفيف

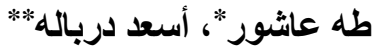

تعتبر المحارة بالمواد الطبيعية مثل الطين من أهم لوازم المبانى الطبيعية، وخاصة التي تستخدم

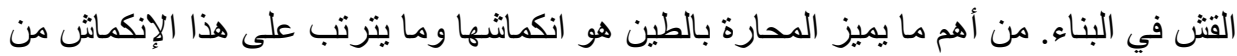

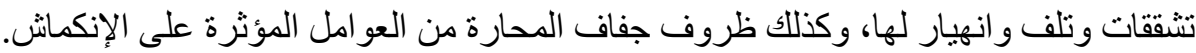

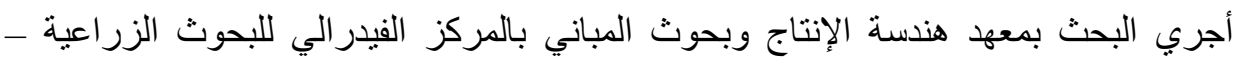

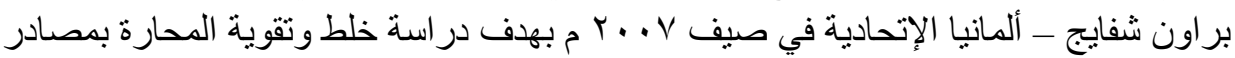

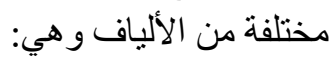

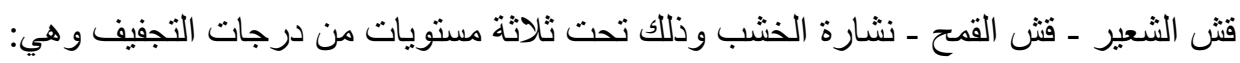

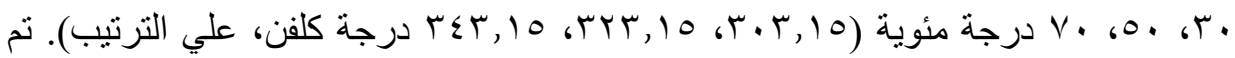

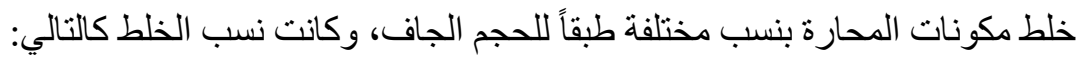

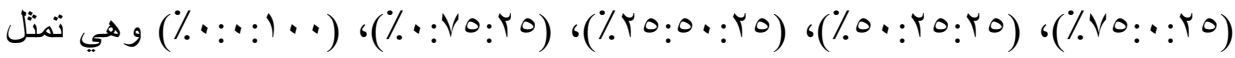

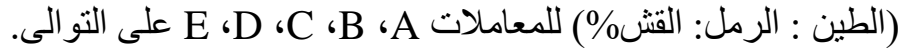

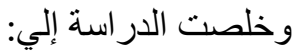

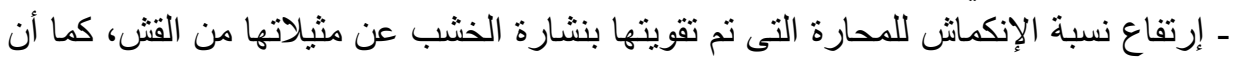

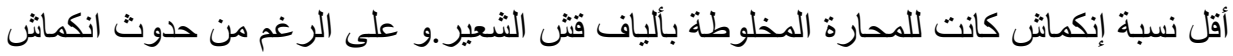
بسيط للمعاملات التى تم خلطها بالألياف، إلا أنه لم تحدث تشققات للمحارة حيث الن أن الخلط يربط المحارة جيداً. ـ أظهرت المعامله E أكثر إنكماش وأكثر تشقق لكونها طين فقط بدون رمل وبدون خلط بالألياف. ـ كان مدى متوسط نسبة الإنكماث للتثلاثة أنو اع من الألياف التى تم تقوية المحارة بها للمعاملات A6B ، C

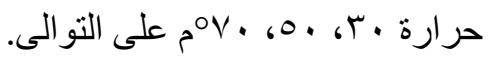

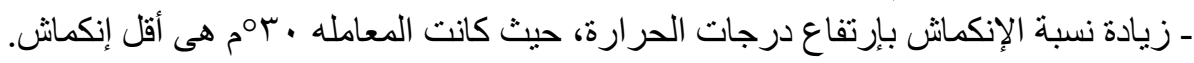

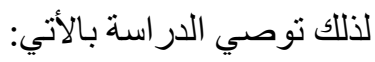

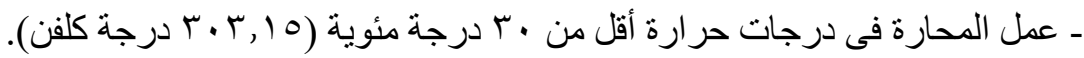

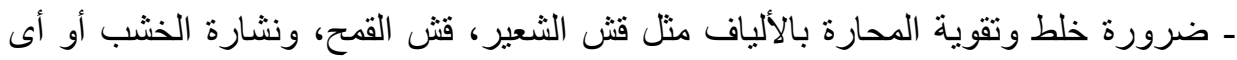
نوع من أنواع القش مثل فش الأرز وذللك لتقليل الإنكماش وحماية المحارة.

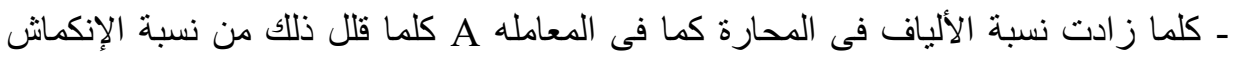

وتشققات المحارة.

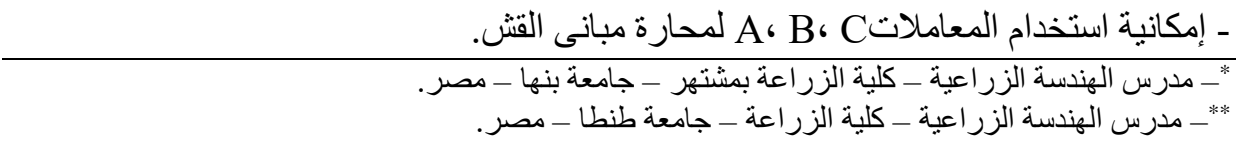

